\title{
Pemanfaatan Teknik Pemodelan Digital untuk Meningkatkan Kualitas Bentuk dan Ergonomi pada shoe last Sepatu
}

\author{
Mohamad Arif Waskito \\ Program Studi Desain Produk, Institut Teknologi Nasional, Bandung, Indonesia \\ Email: mawaskito@itenas.ac.id
}

Received 24 November $2020 \mid$ Revised 12 Januari 2021 | Accepted 12 Januari 2021

\begin{abstract}
ABSTRAK
Pada produk sepatu, kenyaman pakai merupakan faktor penting yang harus diperhatikan. Oleh karena itu sepatu yang baik akan memperhatikan kualitas bentuk dan ukuran shoe last pada saat pembuatannya. Ketidaksesuaian bentuk dan ukuran sepatu yang pakai pada kaki akan beresiko menyebabkan cedera secara temporer, bahkan untuk penggunaan dalam waktu lama dapat menimbulkan kecacatan pada kaki. Namun di industri kecil/menengah (IKM) alas kaki penentuan bentuk dan ukuran produk shoe last umumnya tidak melalui prosedur verifikasi yang baku. Penggunaan teknologi pemodelan digital pada pembuatan shoe last akan dapat membantu meningkatkan kualitas bentuk dan ukuran yang dihasilkannya. Melalui metode eksperimentasi digital yang didukung dengan data antropometri anatomi kaki responden lokal diharapkan akan menghasilkan sebuah metode baku perancangan shoe last tersebut. Metode perancangan digital untuk produk shoe last ini diharapkan akan bermanfaat bagi para pelaku usaha kecil alas kaki agar kualitas kenyamanan sepatu yang dibuatnya menjadi lebih baik dan berstandar.
\end{abstract}

Kata kunci: Pemodelan digital, shoe last, IKM, kualitas kenyamanan

\begin{abstract}
In shoe products, wear comfort is an important factor that must be considered. Therefore, good shoes will pay attention to the quality of the shape and size of the last shoe at the time of manufacture. The improper shape and size of the shoes that are used on the feet will risk causing temporary injury, even for prolonged use, it can cause disability in the feet. However, in the small / medium-sized footwear industry (IKM), determining the shape and size of shoe last products generally does not go through a standard verification procedure. The use of digital modeling technology in making shoe lasts will help improve the quality of the shape and size it produces. Through the digital experimentation method that is supported by anthropometric data on the anatomy of the local respondents' feet, it is hoped that it will produce a standard method of designing the shoe last. It is hoped that this digital design method for shoe last products will be useful for small footwear entrepreneurs so that the quality of the comfort of the shoes they make becomes better and standard.
\end{abstract}

Keywords: Digital modeling, shoe last, SMEs, comfort quality

\section{PENDAHULUAN}

Pengembangan produk shoe last (sejenis alat cetak untuk menghasilkan sepatu dengan bentuk dan ukuran tertentu) adalah hal yang penting dalam usaha untuk menghasilkan kualitas kenyamanan produk alas kaki karena aspek kenyamanan pada produk alas kaki akan berawal pada kesesuaian kaki dengan sepatunya (fitness). Untuk pembuat sepatu, shoe last memegang peranan penting dalam merepresentasikan ciri-ciri bentuk kaki manusia, sekaligus meningkatkan kenyamanan pemakaiannya 
[1]. Kinerja sebuah produk dapat dievaluasi secara luas berdasarkan fungsinya (yaitu produk bekerja seperti yang dirancang), bentuk (menarik bagi mata), dan kesesuaian ("cocok" dengan tujuan). Di dalam banyak kasus, kesesuaian dapat mengendalikan faktor fungsional dan oleh karenanya hal tersebut merupakan sebuah kriteria penting [2].

Perancangan alas kaki telah dikembangkan sejak lama dan dalam beberapa penelitian tentang alas kaki selalu fokusnya pada ergonomi dan fisiologi [3]. Sedangkan pada umumnya para pembuat alas kaki, terutama di kelompok Usaha Kecil Menengah (IKM), hal yang berkaitan dengan bentuk anatomi kaki dan dimensi sering kali dikesampingkan. Mereka lebih mengutamakan aspek bentuk dan fashion saja, tanpa banyak memperhitungkan faktor kenyamanan yang didipengaruhi oleh bentuk dan dimensinya. Sebagai contoh perancangan alas kaki yang berhak tinggi (high heel), secara umum masih mengutamakan aspek fashion/tampilan dan mengesampingkan pertimbangan ergonomi yang dapat menjadi penyebab permasalahan pada kaki [3]. Variasi yang signifikan ada di antara populasi yang berbeda ketika mempertimbangkan faktor-faktor ini. Misalnya, wanita mungkin lebih menekankan pada fashion daripada fit, dan mungkin siap membayar harga tinggi untuk sepatu mereka [8]. Sepatu yang tidak nyaman sering dikaitkan dengan penyebab nyeri kaki dan patologi, dengan $60 \%$ subjek wanita mengalami nyeri kaki terkait dengan sepatu yang dikenakannya [4]. Oleh karena itu penting untuk dipahami oleh para pembuat sepatu bahwa terdapat korelasi yang kuat antara bentuk, konstruksi anatomi dan dimensi pada kaki yang harus tepat diimplementasikan pada bentuk, dan dimensi shoe last yang diterapkan pada proses pembuatan sepatunya.

Pembuatan shoe last merupakan proses awal yang akan menentukan kualitas produk alas kaki, tidak hanya untuk mendapatkan bentuk sebagai respon dari kebutuhan pasar saja, namun proses pembuatan shoe last yang baik akan mempengaruhi kualitas kenyamanan produk tersebut sehingga nantinya akan turut menentukan penguatan identitas dan kareakter industri sebagai keunggulannya.

Industri yang fokus pada pengembangan produk melalui peningkatan kualitas fungsi, kenyamanan, dan desainnya akan menjadikan proses pembuatan shoe last sebagai hal yang sangat penting untuk dilakukan. Salah satu usaha yang dilakukan untuk menjaga kualitas kenyamanan produk sepatu adalah kegiatan memverifikasi shoe last yang dimiliki. Proses verifikasi dilakukan melalui pengukuran dan pembentukan ulang dari sebuah produk shoe last yang akan digunakan pada proses pembuatan produk alas kaki secara masal. Proses verifikasi yang dilakukan secara konvensional biasanya akan memakan waktu lama dan biaya yang cukup besar karena proses modifikasi dan revisi dimensi atau bentuk shoe last tersebut harus dilakukan secara berulang-ulang.

Pada saat pembuatan produk shoe last, para pembuat shoe last biasanya menggunakan peralatan konvensional/manual untuk pembuatan shoe last dan kemudian dilanjutkan dengan penggunaan mesin copy shoe last untuk membuat "pasangan shoe last" atau membuat shoe last serial. Pembuatan shoe last dengan cara konvensional ini akan mempengaruhi kualitas produk tersebut karena pengerjaan dengan cara manual (hand made) memungkinkan menghasilkan bentuk dan ukuran yang tidak standar. Oleh karena itu dengan berkembangnya teknologi digital, maka sekarang dimungkinkan untuk memanfaatkan program aplikasi 3D pada proses perancangan shoe last di komunitas perajin industri kecil-menengah (IKM) tersebut.

Tujuan dari menelaah penggunaan mesin 3D Printing ini adalah melihat peluang keberadaan teknologi digital untuk dapat digunakan di industri kecil sebagai salah satu usaha untuk peningkatan kualitas produk yang mereka hasilkan. Revolusi Industri 4.0 telah memberdayakan peranan digital dalam dunia manufaktur. Kegiatan perancangan, produksi dan distribusi telah banyak menggunakan teknologi informasi untuk mendistribusikan banyak hal dari berbagai sumber dan lokasi, yang semula bersifat fisik menjadi objek digital. Kondisi tersebut sudah banyak ditemui dalam dunia manufaktur, namun pada dunia industri kecil-menengah masih banyak hal yang harus dibenahi. Kendala yang seringkali ditemui dalam pemanfaatan teknologi digital di sektor industri kecil-menengah adalah keengganan para palaku usaha tersebut untuk dapat melibatkan hal-hal yang baru dalam kegiatan produksinya. Peneliti menilai bahwa industri kecil-menengah pada hakekatnya memiliki keinginan untuk selalu mengembangkan produknya melalui pemanfaatan kebaruan-kebaruan tertentu, namun pada umumnya 
keinginan tersebut seringkali terhambat oleh kapablitas SDM yang rendah, nilai investasi alat/teknologi yang cukup besar, dan keberanian untuk melakukan hal-hal baru karena akan membutuhkan biaya riset yang cukup besar.

Pada penelitian ini telah dikaji sampai sejauh mana metode verifikasi shoe last dengan menggunakan teknologi digital dengan dukungan data antropometri kaki para pengguna sepatu lokal sehingga dapat direalisasikan pada bentuk dan dimensi sebuah produk shoe last dengan bantuan mesin 3D printing. Diharapkan pula data anthropometri yang didapat dari responden akan dijadikan acuan dasar para perajin sepatu untuk dapat membuat sendiri shoe last dengan dimensi anatomi kaki standar untuk konsumen lokal.

\section{METODOLOGI}

Pengkajian terhadap kualitas shoe last dilakukan melalui metode analisis anthropometri pada data kaki responden yang visualisasinya dibantu dengan sebuah aplikasi pemodelan digital. Metode ini dilakukan melalui tahap-tahap sebagai berikut:

1. Pengumpulan data anthropometri kaki responden dilakukan melalui survey dan pengukuran secara konvensional terhadap dimensi anatomi kaki, yaitu pada bagian-bagian kaki: panjang telapak kaki, keliling ball, keliling waist, keliling instep, keliling heel.

2. Kegiatan menganalisis kesesuaian dimensi anthropometri kaki responden yang didapat dari kegiatan survey dengan dimensi anthropometri yang diterapkan pada shoe last yang menggunakan sistem standarisasi ukuran sepatu untuk komunitas masyarakat lokal, yang biasa digunakan sebagai acuan oleh para pembuat alas kaki.

3. Analisis komparasi kualitas shoe last yang dihasilkan industri pembuat (pabrikan) produk shoe last dengan perancangan produk shoe last yang dihasilkan melalui kegiatan pemodelan digital.

Gambar 1 di bawah menunjukkan alur riset yang dimulai dari kegiatan survey untuk mendapatkan data antropometri kaki dari para responden dalam sebuah komunitas lokal. Data tersebut kemudian dibandingkan dengan data antropometri dari shoe last standar yang dimensi anatominya didapat berdasarkan rujukan dari sistem penomoran yang berlaku universal.

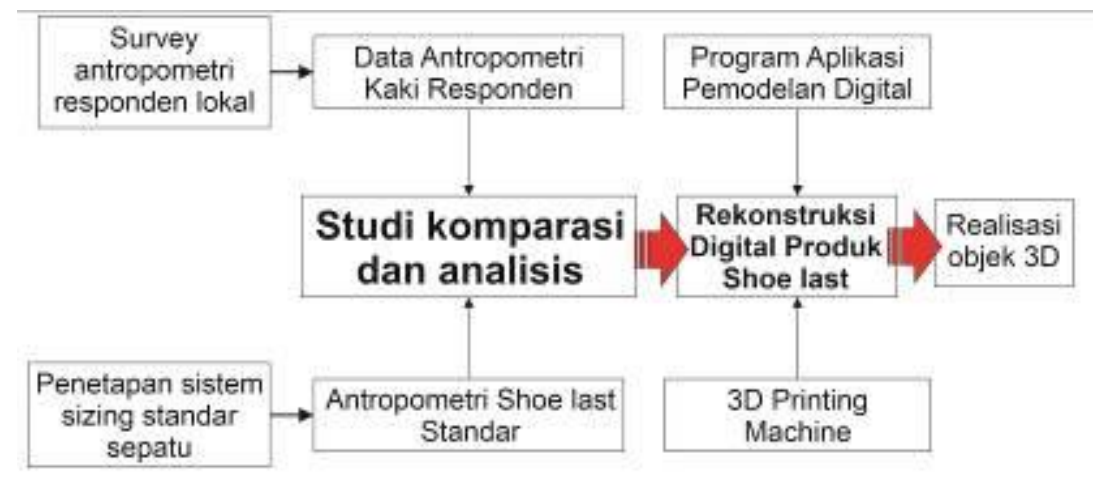

Gambar 1. Skema Kerangka Berpikir Penelitian

Hasil komparasi dan analisis dimensi tersebut kemudian direkonstruksi dakam bentuk pemodelan digital yang akhirnya diwujudkan dalam bentuk objek 3 dimensional. shoe last eksperimental yang dihasilkan dari kegiatan rekonstruksi ini akan menjadi shoe last rujukan yang dapat digunakan oleh para pembuat sepatu. 


\subsection{Penetapan sistem penomoran sepatu metode Paris Point sebagai pembanding}

Kriteria yang valid untuk membuat sepatu yang sesuai dengan kaki dengan ukuran dan bentuk yang berbeda harus ditetapkan [10]. Untuk mendapatkan gambaran riil dari hubungan antara bentuk dan dimensi anatomi shoe last yang digunakan oleh para pembuat sepatu lokal dengan ukuran kaki konsumennya maka dilakukan beberapa kegiatan penelusuran anatomi kaki dari sekelompok masyarakat lokal sebagai studi kasusnya. Data diambil dari 60 responden pria dengan kelompok usia 17 - 30 tahun. Data dimensi anatomi kaki yang diambil adalah pada bagian-bagian kaki tertentu, yaitu: bagian panjang telapak kaki, keliling ball, keliling waist, keliling instep, dan keliling heel. Bagianbagian tersebut biasanya dijadikan titik-titik tempat merekonstruksi data dimensional menjadi objek visual 3 dimensi. mendapatkan gambaran riil dari hubungan antara bentuk \& dimensi anatomi shoe last yang digunakan oleh para pembuat sepatu maka dilakukan beberapa kegiatan penelusuran anatomi kaki dari sekelompok masyarakat lokal sebagai studi kasusnya. Data diambil dari 60 responden pria dengan kelompok usia 17 - 30 tahun. Data dimensi anatomi kaki yang diambil adalah pada bagianbagian kaki tertentu, yaitu: bagian panjang kaki, keliling ball, keliling waist, keliling instep, dan keliling heel (Gambar 2). Bagian-bagian tersebut biasanya dijadikan titik-titik tempat merekonstruksi data dimensional menjadi objek visual.

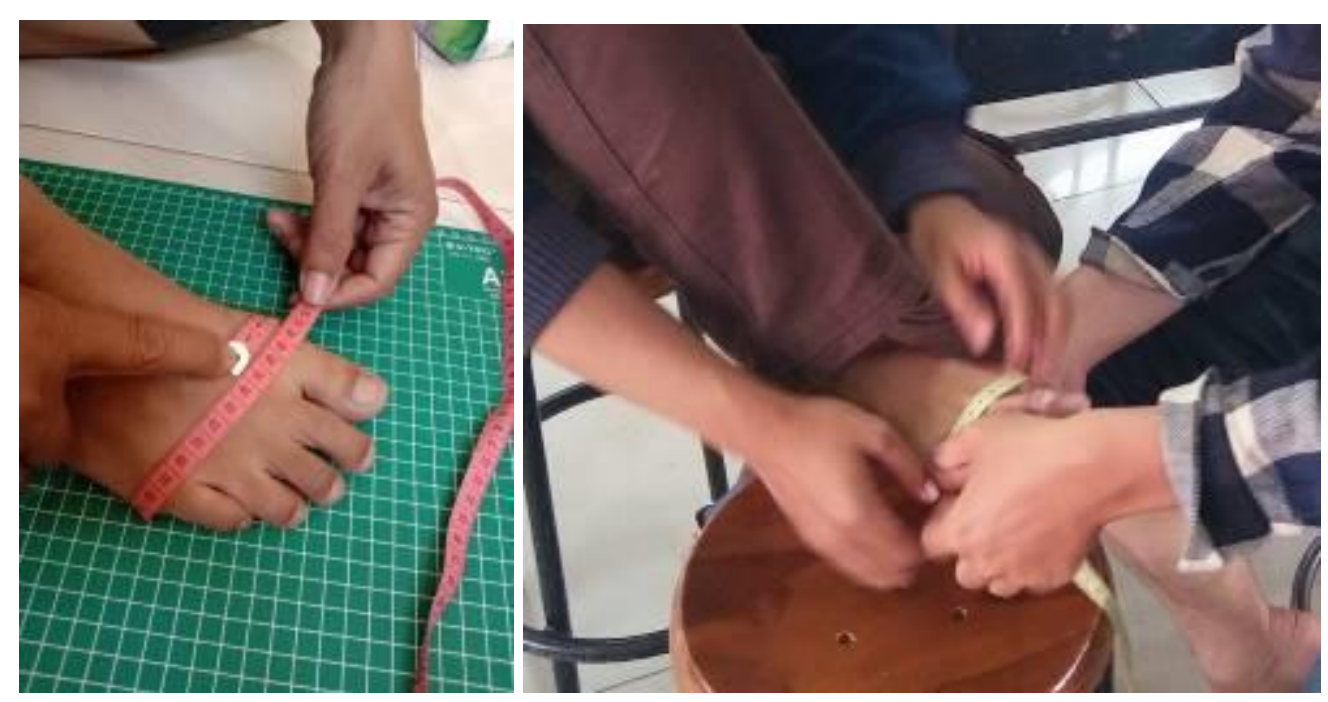

Gambar 2. Pengumpulan data antropometri kaki responden

(Sumber: Dok. Pribadi, 2020)

Tujuan dari kegiatan pengumpulan data ini adalah untuk mendapatkan beberapa hal yang penting sebagai rujukan, diantaranya:

1. Sebaran nomor sepatu yang mana yang dominan digunakan oleh responden, sehingga data tersebut dapat digunakan untuk menjadi rujukan nomor sepatu yang harus paling banyak dihasilkan oleh para pembuat sepatu.

2. Ukuran rata-rata dari bagian panjang telapak kaki dan bagian ball kaki responden, yang nantinya akan digunakan sebagai acuan ukuran pada saat membuat sebuah shoe last

3. Mengidentifikasi apakah sistem penomoran yang digunakan oleh para pembuat sepatu sudah sesuai dengan sistem penomoran yang berlaku secara universal atau tidak. Harapannya para pembuat sepatu dapat menggunakan data anthropometri responden-responden tersebut sebagai dasar pembuatan shoe last sehingga produk sepatu yang dihasilkan memiliki bentuk dan ukuran yang sesuai dan berlaku universal untuk konsumennya.

Data yang didapat dari survey digunakan untuk merekonstruksi sebuah shoe last dalam bentuk objek digital melalui program aplikasi pemodelan 3 dimensional. Program aplikasi yang digunakan mampu merekonstruksi data dimensional menjadi objek visual dalam bentuk mesh modeling. Hasil rekonstruksi yang berbentuk shoe last digital tersebut kemudian dikomparasi dengan dimensi anatomi shoe last standar pada tabel sistem penomoran internasional. 
Sistem penomoran/ukuran yang akan menjadi rujukan adalah sistem Eropa (EU), yang juga dikenal sebagai sistem "Paris Point" seperti yang ditampilkan pada gambar 3. Titik Paris sekarang dianggap sebagai sistem ukuran sepatu standar di Eropa daratan dan oleh karena itu juga disebut sebagai "Ukuran Prancis", "Ukuran Eropa", "Ukuran sepatu UE", atau "Ukuran Jerman" [7]. Sistem ini sudah dikenal sejak tahun 1800-an, yang kemudian penggunaannya menyebar hampir ke seluruh wilayah Eropa dengan menggunakan sistem matrik $(\mathrm{cm})$, kecuali daratan Inggris yang masih menggunakan skala pengukuran empirial (inchi).

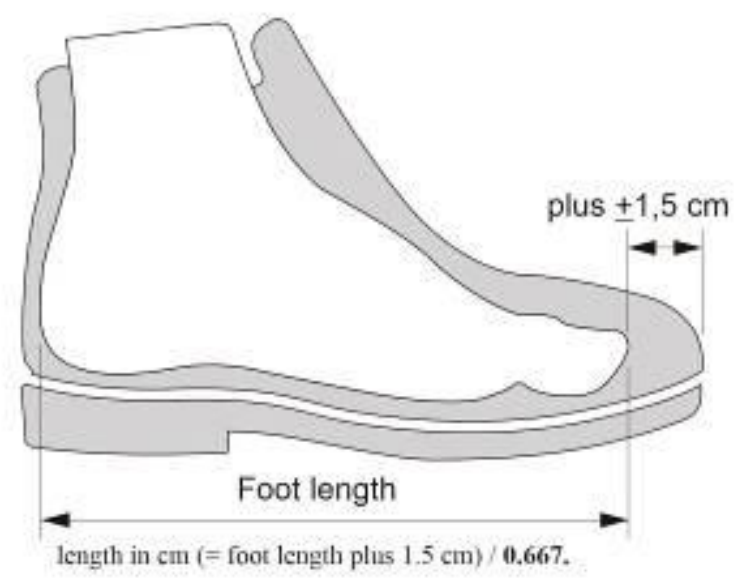

Gambar 3. Cara menomori sepatu dalam system ukuran Paris Point

Paris Point (atau sistem ukuran Eropa) berasal dari panjang jahitan asli dari jahitan ganda mesin jahit. Panjang setiap jahitannya sama dengan dua pertiga sentimeter $(0,667 \mathrm{~cm})$. Pada sistem Eropa, penomoran sepatu ditentukan berdasarkan perhitungan: panjang shoe last dalam $\mathrm{cm}$ (= panjang kaki ditambah $1,5 \mathrm{~cm}) / 0,667$. [7]. Nilai $1,5 \mathrm{~cm}$ adalah ruang kosong diujung sepatu yang keberadaannya ditambahkan untuk memberikan ruang gerak pada kaki saat berjalan, sehingga akan terasa lebih nyaman.

Sistem Paris Point kemudian diadopsi oleh beberapa negara Asia termasuk Indonesia sehingga hingga saat ini di Indonesia lebih banyak ditemukan sepatu dengan label penomoran 40,41,42 dan seterusnya. Sistem penomoran sepatu yang dapat dilihat pada table 1 di bawah menggunakan pengukuran shoe last dengan model sepatu bentuk dasar, yaitu model sepatu dengan bentuk shoe last yang dibuat berdasarkan anatomi kaki kemudian hanya ditambahkan "toe box" (ruang di depan ujung kaki) sepanjang $1,5 \mathrm{~cm}$.

Tabel 1 di bawah adalah tabel konversi antara panjang kaki dengan ukuran sepatu berdasarkan sistem penomoran Paris Point/Eropa, UK, dan US. 
Tabel 1. Tabel konversi system ukuran Paris Point

\begin{tabular}{|c|c|c|c|c|}
\hline $\begin{array}{c}\text { Panjang } \\
\text { Kaki }\end{array}$ & $\begin{array}{c}\text { D / EU shoe } \\
\text { size }\end{array}$ & $\begin{array}{l}\text { UK shoe } \\
\text { size }\end{array}$ & $\begin{array}{l}\text { US ladies } \\
\text { shoe size }\end{array}$ & $\begin{array}{l}\text { US men's } \\
\text { shoe size }\end{array}$ \\
\hline $22,2 \mathrm{~cm}$ & 35 & 3 & $41 / 2$ & - \\
\hline $22,6 \mathrm{~cm}$ & 36 & $31 / 2$ & 5 & - \\
\hline $23,1 \mathrm{~cm}$ & 37 & 4 & $51 / 2$ & - \\
\hline $23,5 \mathrm{~cm}$ & $371 / 2$ & $41 / 2$ & 6 & - \\
\hline $23,9 \mathrm{~cm}$ & 38 & 5 & $61 / 2$ & - \\
\hline $24,3 \mathrm{~cm}$ & 39 & $51 / 2$ & 7 & $61 / 2$ \\
\hline $24,8 \mathrm{~cm}$ & $391 / 2$ & 6 & $71 / 2$ & 7 \\
\hline $25,2 \mathrm{~cm}$ & 40 & $61 / 2$ & 8 & $71 / 2$ \\
\hline $25,6 \mathrm{~cm}$ & 41 & 7 & $81 / 2$ & 8 \\
\hline $26,0 \mathrm{~cm}$ & $411 / 2$ & $71 / 2$ & 9 & $81 / 2$ \\
\hline $26,5 \mathrm{~cm}$ & 42 & 8 & $91 / 2$ & 9 \\
\hline $26,9 \mathrm{~cm}$ & $421 / 2$ & $81 / 2$ & 10 & $91 / 2$ \\
\hline $27,3 \mathrm{~cm}$ & 43 & 9 & $101 / 2$ & 10 \\
\hline $27,7 \mathrm{~cm}$ & 44 & $91 / 2$ & 11 & $101 / 2$ \\
\hline $28,1 \mathrm{~cm}$ & $441 / 2$ & 10 & $111 / 2$ & 11 \\
\hline $28,6 \mathrm{~cm}$ & 45 & $101 / 2$ & 12 & $111 / 2$ \\
\hline $29,0 \mathrm{~cm}$ & 46 & 11 & - & 12 \\
\hline $29,4 \mathrm{~cm}$ & $461 / 2$ & $111 / 2$ & - & $121 / 2$ \\
\hline $29,8 \mathrm{~cm}$ & 47 & 12 & - & 13 \\
\hline $30,2 \mathrm{~cm}$ & 48 & $121 / 2$ & - & $131 / 2$ \\
\hline $30,6 \mathrm{~cm}$ & $481 / 2$ & 13 & - & 14 \\
\hline $31,0 \mathrm{~cm}$ & 49 & $131 / 2$ & - & $141 / 2$ \\
\hline $31,4 \mathrm{~cm}$ & $491 / 2$ & 14 & - & 15 \\
\hline $31,8 \mathrm{~cm}$ & 50 & $141 / 2$ & - & $151 / 2$ \\
\hline $32,2 \mathrm{~cm}$ & $501 / 2$ & 15 & - & 16 \\
\hline
\end{tabular}

Sumber: https://www.sioux-shop.co.uk/cms/shoe-know-how/shoe-size-and-fit/shoe-size-conversion/

\subsection{Kegiatan pemodelan digital produk shoe last}

Salah satu kegiatan yang dilakukan pada penelitian ini adalah merekonstruksi data anatomi kaki responden untuk diimplementasikan pada produk shoe last. Proses rekonstruksi ini akan menggunakan panjang kaki rata-rata dan keliling ball rata-rata untuk nomor sepatu 41, seperti yang ditunjukkan pada gambar 4. Penggunaan nomor 41 ini ditetapkan karena berdasarkan survey yang telah dilakukan, nomor 41 adalah nomor yang paling banyak digunakan responden $(41,7 \%)$.

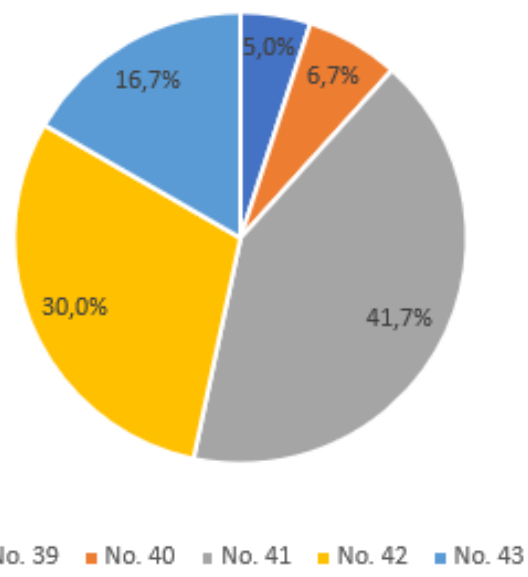

Gambar 4. Distribusi responden berdasarkan nomor sepatu yang mereka gunakan 
Penggunaan nomor 41 bertujuan agar studi komparatif dan proses rekonstruksi shoe last akan berdampak lebih efektif jika diimplementasikan pada kegiatan pembuatan shoe last di industri. Para pembuat shoe last akan menentukan sebuah shoe last dengan nomor tertentu untuk dijadikan acuan saat membuat shoe last serial. Biasanya shoe last dengan penggunaan terbanyaklah yang digunakan sebagai acuan tersebut.

Kegiatan studi komparasi dan rekonstruksi shoe last berdasarkan data anatomi yang didapat dari survey akan menggunakan program pemodelan digital Rhinoceros Versi 5.0®. Program ini dipilih karena dapat digunakan untuk merekontruksi data numerik anatomi kaki dalam bentuk visualisasi digital seperti pada gambar 5, menganalisis dimensi objek berbentuk organic/biomorf dan dapat digunakan untuk memodifikasi bentuk dan ukuran produk shoe last agar lebih optimal.

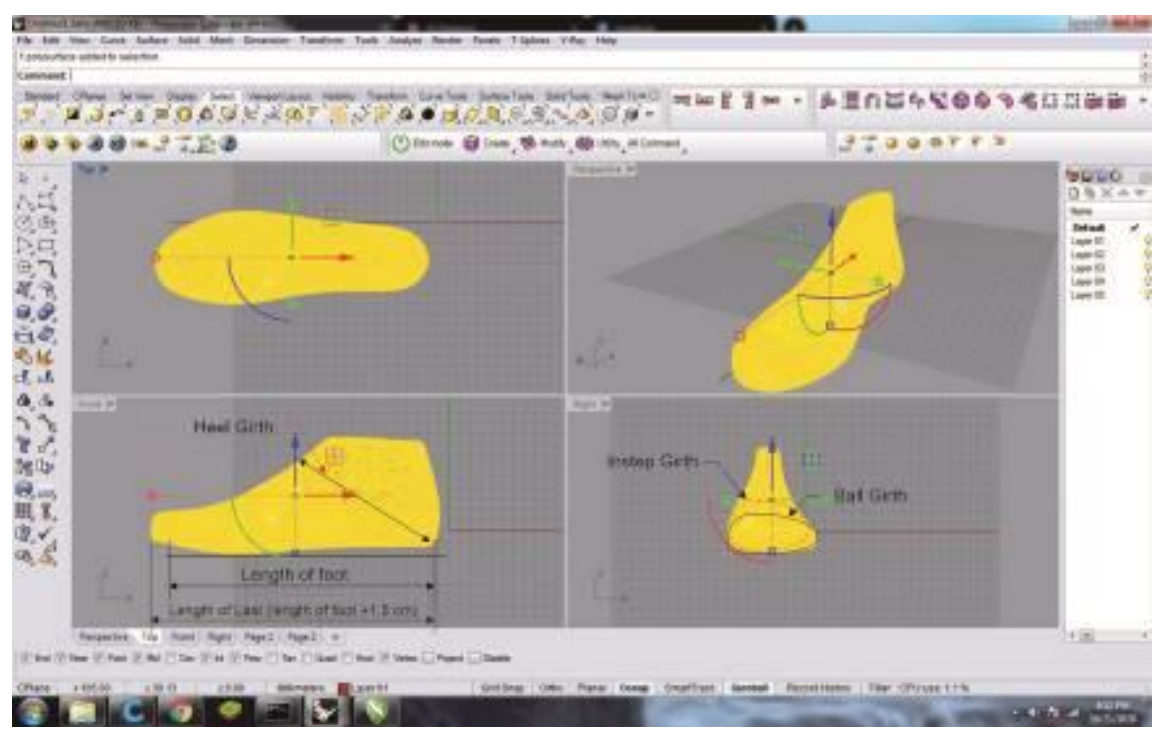

Gambar 5. Bagian-bagian penting dari shoe last sepatu

Beberapa fitur yang terdapat pada program ini memungkinkan untuk memberi informasi tidak hanya bentuk, namun juga informasi dimensi dari setiap objek 3D yang ditampilkannya. Dalam penelitian ini digunakan model digital sebuah shoe last berbentuk dasar yang dimensi anatominya sudah sesuai dengan dimensi acuan. Bentuk dan dimensi standar ini digunakan sebagai dimensi pembanding pada kegiatan rekonstruksi shoe last yang dibuat berdasarkan dimensi anatomi kaki para responden.

Proses komparasi dimensi anatomi shoe last standar dengan dimensi anatomi yang dihasilkan dari proses rekonstruksi berbasis data survey menjadi sangat penting untuk dijadikan dasar rekomendasi dalam pembuatan shoe last acuan. shoe last yang dibuat dengan menggunakan data survey anatomi riil dari para responden nantinya akan menjadi acuan untuk pembuatan shoe last serial sesuai dengan sistem penomoran yang telah ditetapkan. Sehingga diharapkan jika basis data ukuran shoe last menggunakan data riil anatomi responden, maka produk sepatu yang dihasilkan oleh IKM akan semakin fit dengan ukuran kaki konsumennya.

\section{DATA DAN PEMBAHASAN}

\subsection{Pemetaan pengguna nomor sepatu dalam masyarakat lokal}

Responden yang berkontribusi dalam kegiatan pengumpulan data anatomi kaki pengguna sepatu umumnya berlatarbelakang karyawan. Responden menggunakan sepatu dalam beragan jenis dan model, mulai dari model sepatu formal, sepatu kasual maupun sepatu sport. Masing-masing memiliki 
sepatu favorit yang menjadi andalannya untuk melakukan kegiatan kesehariannya. Dari hasil survey tersebut, diketahui nomor sepatu yang paling banyak dikenakan oleh masyarakat (responden) di wilayah Bandung dan sekitarnya adalah sepatu nomor 41 (41,7\%), dengan panjang kaki rata-rata 25,33 $\mathrm{cm}$. Dari hasil pengumpulan data lapangan seperti yang ditunjukkan pada gambar 6 , sepatu dengan nomor 41 berada pada rentang panjang tapak kaki 24,6- 25,6 cm, sedangkan berdasarkan tabel standar penomoran Paris Point ukuran panjang kaki 24,6 cm seharusnya diberi nomor 391/2, dan untuk ukuran danjang kaki 25,6 cm diberi nomor 41 .

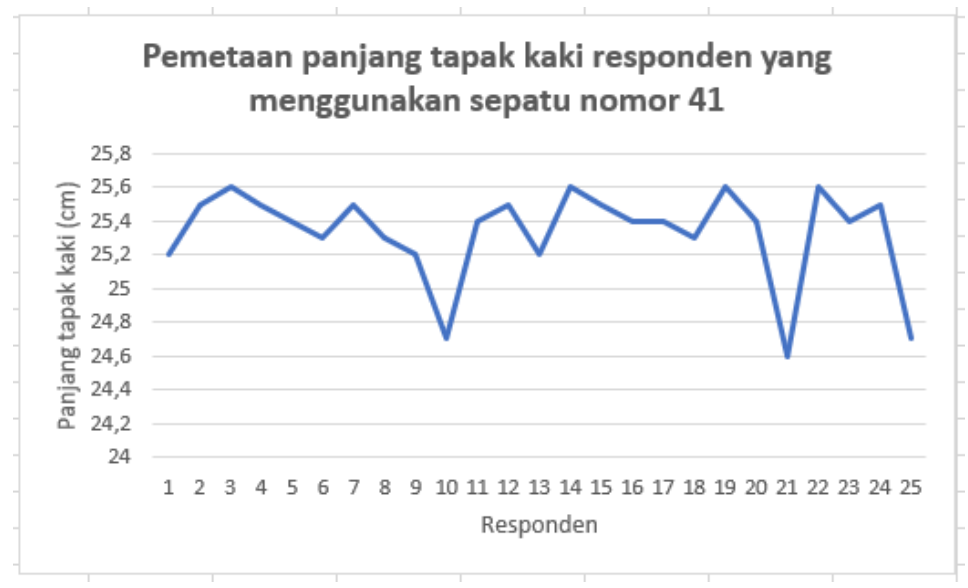

\section{Gambar 6. Pemetaan Panjang tapak kaki responden pengguna sepatu nomor 41}

Dengan ditemukannya responden yang menggunakan nomor 41 tetapi memiliki panjang kaki 24,6 cm, hal ini menunjukkan bahwa masih ada produsen sepatu yang menggunakan shoe last tidak berpatokan pada ukuran-ukuran standar yang bersifat universal. Dari suvey juga didapati 25 orang responden yang menggunakan sepatu berukuran 41 , ada 22 orang responden yang panjang kakinya antara 25,2 - 25,6 $\mathrm{cm}$. Sedangkan 3 orang diantaranya lebih pendek dari ukuran tersebut. Temuan ini menunjukkan bahwa masih ada industri-industri yang memiliki shoe last dengan ukuran lebih kecil dari ukuran standar yang digunakan secara umum.

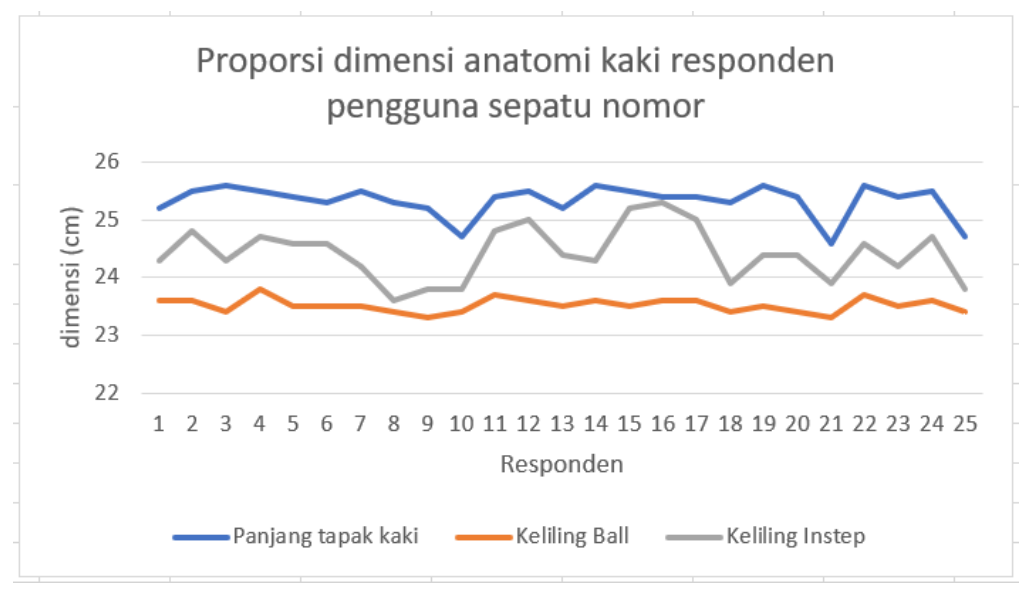

\section{Gambar 7. Proporsi anatomi kaki (Panjang tapak, keliling ball/ metatarsal, dan keliling tumit)} Responden pengguna sepatu nomor 41

Nomor 41 sebagai ukuran sepatu yang sering digunakan masyarakat, dapat digunakan juga menjadi acuan untuk pembuatan pola dasar sebuah model sepatu. Seperti juga produk shoe last sebagai alat bantu produksi, pembuatan pola dasar penting kedudukannya dalam memulai proses pembuatan sebuah sepatu. Pada proses pembuatan pola, awal kegiatan dimulai dengan memindahkan desain model sepatu untuk digambar pada permukaan sebuah shoe last. Pada umumnya shoe last yang 
digunakan adalah shoe last dengan nomor yang paling dominan. Oleh karena itu jika diketahui bahwa nomor dominan adalah 41, maka pola dasar yang dibuat juga sebaiknya menggunakan pola ukuran 41 . Pola ukuran 41 ini kemudian akan diduplikasi secara serial (grading) berdasarkan nomor-nomor yang dibutuhkan, baik penomoran yang semakin mengecil $(40,39$, dst) maupun nomor-nomor yang semakin membesar $(42,43, \mathrm{dst})$.

Dari hasil studi, dimensi rerata anatomi pada responden yang menggunakan sepatu nomor 41 dapat dilihat gambarannya bahwa proporsi antara ukuran panjang kaki, keliling ball dan keliling instep 25 responden tersebut sangat fluktuatif. Gambaran proporsi ini, seperti yang ditunjukkan pada Gambar 7, merupakan sebuah kondisi riil mengingat bahawa kaki sebagai objek natural akan berbeda ukurannya pada setiap orang. Pada penomoran produk sepatu biasanya akan dibagi dalam tiga katagori ukuran, yaitu ukuran slim (kurus), normal, dan lebar. Biasanya perbandingan tersebut dilakukan dengan menggunakan dua parameter yang paling banyak dilakukan yaitu panjang kaki sebagai konstantanya, dan keliling ball sebagai variabelnya. Jika melihat pada grafik di atas, kita dapat mengambil contoh kasus yaitu pada responden nomor $2,4,7,12,15$, dan 24 . Keenam responden tersebut memiliki panjang telapak kaki yang sama yaitu $25,5 \mathrm{~cm}$. Namun jika kita lihat pada ukuran keliling ball berkisar antara 23,5-23,8 cm. Sehingga proporsi anatomi kaki responden tersebut akan mempengaruhi dimensi anatomi shoe last dari produk sepatu yang mereka kenakan.

Gambaran awal dari hasil pengumpulan data anthropometri responden dapat dikenali bahwa proporsi anatomi dari ukuran panjang telapak kaki setiap responden tidak berbanding lurus dengan keliling ball kakinya, sehingga pada saat memilih nomor sepatu, umumnya para responden akan menggunakan parameter panjang telapak kaki terlebih dahulu sebelum mencari ukuran "ball" yang sesuai/fit dengan kakinya.

Ukuran anatomi kaki manusia pada hakekatnya sangat bervariatif, namun untuk sebuah kelompok sosial yang berada pada sebuah wilayah tertentu akan memiliki karakteristik yang serupa. Perbedaan parameter antropometri kaki dalam yang berkaitan dengan ras dan jenis kelamin adalah fakta [4]. Hubungan antara panjang kaki dan lingkar kaki pada populasi wanita dari Asia Tenggara dan Afrika serupa dengan yang ada pada wanita dewasa muda dari seri Japan Leather and Leather-Good Industries Association/JLIA [6].

Proporsi bentuk kaki di kelompok masyarakat Indonesia khususnya yang tinggal di wilayah Bandung dan sekitarnya juga akan memiliki kemiripan karakter, hanya saja kondisi tersebut untuk beberapa produsen sepatu tidak banyak diperhatikan dengan seksama. Hal ini yang sering kali dianggap penyebab terjadinya ketidakstandaran sistem penomoran yang ada dalam komunitas para pembuat sepatu di Bandung. Para pembuat sepatu seringkali menggunakan proporsi shoe last hanya berdasarkan rujukan yang dikeluarkan oleh para pembuat shoe last saja tanpa memferivikasinya dengan sistem penomoran yang berlaku secara universal. Para pembuat sepatu sangat percaya dengan hasil kerja para pembuat shoe last tersebut. Namun sayangnya para pembuat shoe last seringkali menggunakan bentuk sol yang dibeli di toko sebagai rujukannya dan menyerahkan ukuran-ukuran anatomi shoe last pada mesin yang bekerja secara otomatis, tanpa disertai sistem monitoring kualitas yang ketat dan berkala. Alur kerja yang berlaku seperti itu telah membuat kualitas bentuk dan kenyamanan produk-produk alas kaki yang dihasilkan oleh para pembuat sepatu di wilayah Bandung tidak memiliki standarisasi yang baik karena mereka bergantung pada para produsen sol sepatu, yang nota bene memiliki metode perancangan sol yang berbeda-beda.

\subsection{Korelasi antara sistem penomoran dengan dimensi pada produk alas kaki yang ada dalam masyarakat}

Melihat permasalah riil yang menjadi kebiasaan para pembuat shoe last, maka diperlukan kegiatan rekonstruksi shoe last yang data anthropometrinya didapat dari responden yang biasa menjadi konsumen para produsen sepatu di wilawah Bandung. Pada metode penelitian ini digunakan dua 
parameter dimensi anatomi yang akan dikomparasikan, yaitu ukuran anatomi shoe last standar (dengan model bentuk dasar) dan ukuran anatomi kaki responden. Perbandingan dimensional kedua rujukan tersebut menggunakan sampel ukuran sepatu 41 sebagai nomor yang paling dominan dalam komunitas lokal. Perbandingan dimensi anatomi keduanya dapat dilihat pada tabel 2 di bawah ini:

Tabel 2 Perbandingan dimensi anatomi kaki responden dengan dimensi shoe last standar

\begin{tabular}{|l|c|c|c|c|}
\hline & $\begin{array}{c}\text { Panjang } \\
\text { tapak } \\
(\mathrm{cm})\end{array}$ & $\begin{array}{c}\text { Keliling } \\
\text { Ball } \\
(\mathrm{cm})\end{array}$ & $\begin{array}{c}\text { Keliling } \\
\text { instep } \\
(\mathrm{cm})\end{array}$ & $\begin{array}{c}\text { Keliling } \\
\text { tumit } \\
(\mathrm{cm})\end{array}$ \\
\hline $\begin{array}{l}\text { Ukuran anatomi kaki } \\
\text { responden }\end{array}$ & 25,33 & 23,52 & 24,42 & 32,49 \\
\hline $\begin{array}{l}\text { Ukuran anatomi shoe last } \\
\text { standar }\end{array}$ & $\mathbf{2 5 , 6}$ & 24,4 & 25,5 & 33,5 \\
\hline
\end{tabular}

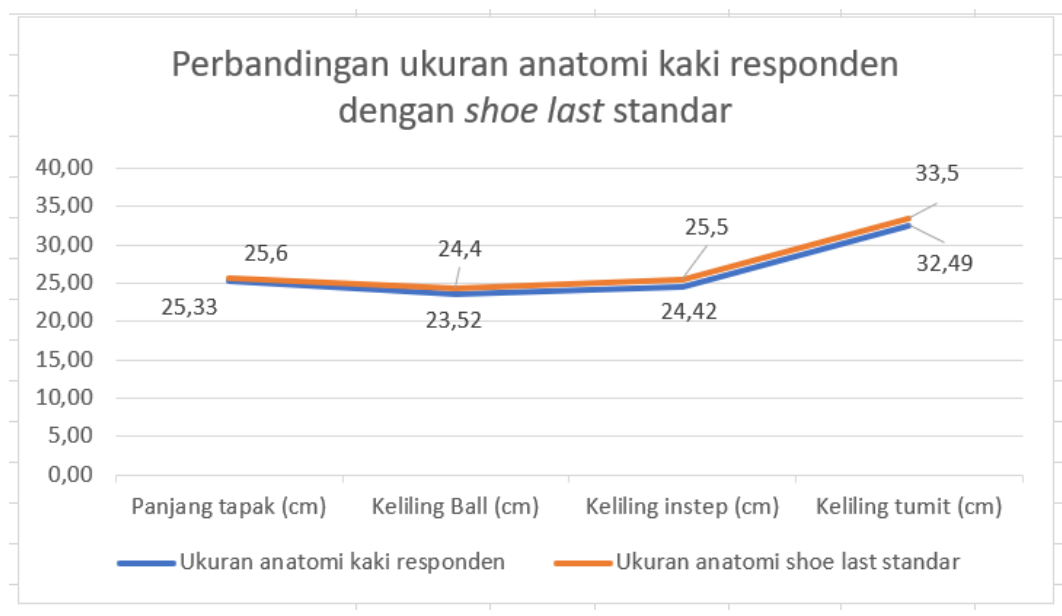

Gambar 8. Perbandingan dimensi anatomi antara shoe last standar dan rerata dimensi anatomi kaki pengguna sepatu nomor 41

Pada Gambar 8 tampak bahwa ukuran rerata dimensi/antropometri kaki masyarakat Bandung pada bagian ball cukup mendekati dimensi ball shoe last standar, yaitu $25,33 \mathrm{~cm}$. Hanya $0,3 \mathrm{~cm}$ perbedaannya dengan ukuran ball pada shoe last. Namun pada bagian keliling ball, keliling instep dan keliling heel ukurannya lebih kecil secara signifikan jika dibanding dengan dimensi shoe last standar, yaitu sekitar $1 \mathrm{~cm}$. Hal ini menunjukkan bahwa ukuran rerata kaki responden lebih ramping dari ukuran standarnya. Perbedaan yang cukup besar pada bagian ball dapat membuat sistem penomoran yang digunakan para pembuat sepatu akan berbeda dengan sistem penomoran universal. Ukuran ball pada shoe last standar yang dicantumkan pada tabel $(25,6 \mathrm{~cm})$ adalah ukuran yang digunakan pada nomor 41, sedangkan jika kita mengacu pada data survey, ukuran keliling ball tersebut umumnya digunakan untuk sepatu dengan nomor 42 .

Ada perbedaan cara penentuan kesesuaian sepatu dengan kaki penggunanya yang dilakukan para pembuat sepatu lokal dengan sistem penomoran sepatu universal. Para pembuat sepatu lokal menentukan kesesuaian sepatu dengan kaki melalui penetapan ukuran keliling ball, sedangkan pada sistem penomoran sepatu yang berlaku universal ditentukannya dengan parameter panjang telapak kaki. Di komunitas pembuat sepatu yang berada di sekitar Bandung, khususnya wilayah Cibaduyut, pada saat ini penentuan penomoran dilakukan melalui pengukuran keliling ball. Ukuran bagian kaki 
tersebut dijadikan acuan untuk menentukan nomor dari sepatu yang dimaksud karena bagian ball adalah bagian terbesar dari penampang kaki. Berdasarkan anggapan tersebut, maka para perajin sering kali mengabaikan standarisasi dimensi dan sistem penomoran yang berlaku secara universal. Umumnya kesesuaian kaki pada sepatu atau kenyamanan pakainya akan ditentukan pada saat mencobanya secara langsung. Tentunya hal ini akan jadi permasalahan yang perlu diperhatikan, khususnya karena sistem pemasaran saat ini banyak mengarah pada pemasaran online.

\subsection{Merekonstruksi shoe last melalui metode pemodelan digital}

Pada sistem penomoran standar Eropa (Paris point), penetapan penomoran sepatu berdasarkan perhitungan sebagai berikut:

Panjang shoe last (“panjang tapak kaki+1.5 cm")/0,667

Seperti yang telah ditunjukkan pada Table 1 di atas, untuk penentuan penomoran standar berdasarkan sistem Paris Point, panjang tapak kaki adalah data input yang digunakan untuk menentukan nomornomor pada produk sepatu. Seseorang yang memiliki panjang tapak kaki 25,6 akan menggunakan sepatu nomor 41, jika berdasarkan rumus di atas maka perhitungannya sebagai berikut:

Panjang Shoe last $(25,6+1,5) / 0,667 \quad=40,63$

$\approx 41$

Sedangkan untuk seseorang yang memiliki panjang tapak kaki dengan ukuran 26,5 akan meggunakan nomor 42.

Panjang Shoe last $(26,5+1,5) / 0,667 \quad=41,97$

$\approx 42$

Namun pada kenyataannya para konsumen seringkali menggunakan ukuran keliling ball untuk menenentukan nomor sepatu yang akan dipakainya. Para pembeli sering kali mencoba beberapa ukuran/nomor sepatu sampai menemukan sepatu dengan tingkat kesesuaian ukuran ball kaki yang paling sesuai. Cara pemilihan ukuran sepatu seperti ini disinyalir yang membuat sistem penomoran pada sepatu-sepatu lokal menjadi berbeda-beda.

Pada kegiatan merekonstruksi objek shoe last digital, ukuran panjang telapak kaki digunakan sebagai parameternya. Kemudian objek tersebut dilengkapi dengan data ukuran bagian-bagian lainnya, yaitu keliling instep $(23,52 \mathrm{~cm})$, keliling ball $(23,53 \mathrm{~cm})$ dan keliling heel $(32,49 \mathrm{~cm})$. Kegiatan rekonstruksi tersebut menghasilkan penampang ball lebih kecil sehingga model shoe last tersebut tampak lebih ramping dari shoe last standar.

Pada program aplikasi 3D modeling Rhinoceros Versi 5.0® terdapat fitur-fitur yang dapat digunakan untuk merekonstruksi data menjadi model shoe last 3 dimensional. Pengkajian ukuran keliling ball dan pengaruhnya terhadap bagian-bagain lain pada anatomi shoe last dapat dilakukan secara optimal. Fitur dengan fungsi scaling, boolean, split, extract curve dan lainnya adalah fitur operasional untuk menghasilkan konstruksi bentuk objek dan modifikasinya. Selain kemampuan dalam membangun sebuah konstruksi objek, program $3 D$ modeling seperti pada Gambar 9, mampu digunakan untuk melakukan analisis terhadap proses rekayasa konstruksi seperti perhitungan luas bidang dan panjang bentangan. Kemampuan seperti ini membuat program 3D modeling Rhinoceros Versi 5.0® dinilai cukup layak digunakan untuk menghasilkan kajian-kajian yang berkaitan dengan pengembangan shoe last tersebut. 


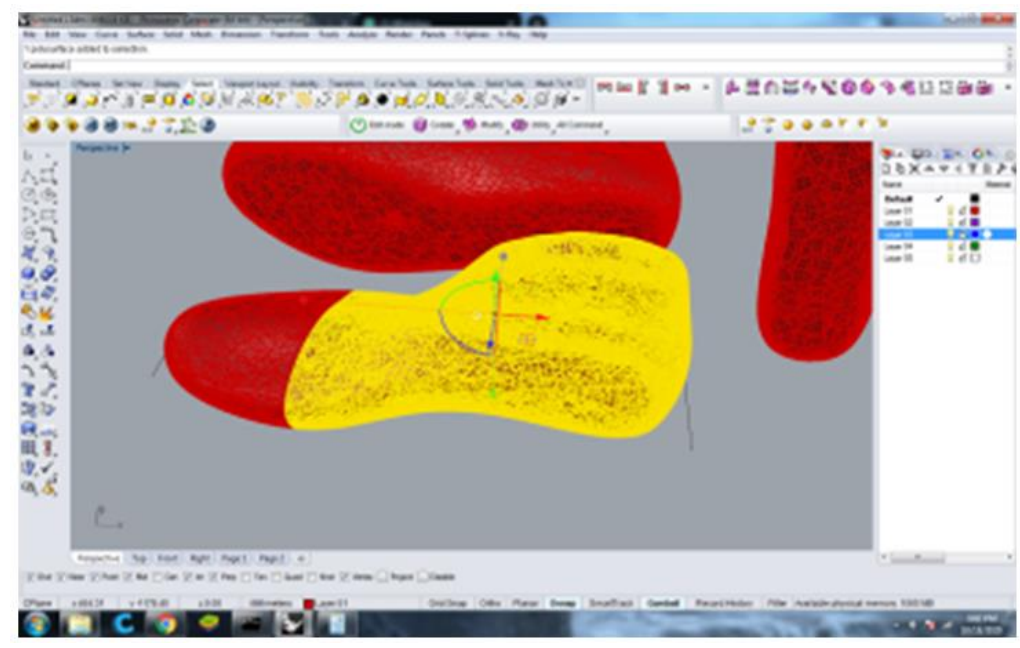

\section{Gambar 9. Penggunaan program Rhinoceros ${ }^{\circledR}$ untuk merekonstruksi data menjadi objek 3D digital}

Rhinoceros sebagai program apikasi digital cukup mampu untuk merekonstruksi dan memvisualisasikan bentuk shoe last yang menggunakan data dari hasil survey. Selain itu program ini mampu pula digunakan untuk merancang dan mengembangkan desain yang ada untuk disesuaikan dengan kebutuhan bentuk dan dimensi baru. Kemampuan tersebut menjadi sangat penting bagi para pembuat shoe last karena kegiatan memodifikasi bentuk dan dimensi shoe last biasanya membutuhkan waktu lama.

Kegiatan merancang dan mengembangkan shoe last dilakukan dengan cara mengidentifikasi penampang pada bagain-bagain yang menjadi titik vitalnya yaitu pada bagian panjang telapak kaki, ball, instep, dan heel. Kemudian dengan program 3D modeling tersebut akan dapat dianalisis ukuran keliling-kelilingnya melalui metode pembagian penampang (bollean split) shoe last sehingga didapatkan gambaran bidang penampangnya. Bidang penampang yang dihasilkan kemudian direkonstruksi menjadi objek 2 dimensional menggunakan fitur "extract surface". Hasil dari proses tersebut kemudian akan didapat sebuah kurva dengan ukuran dan dimensi persis sama dengan penampang bagian shoe last yang sedang ditelaah. Kurva dari bidang-bidang tersebut akan dapat diidentifikasi panjang kelilingnya pada fitur "analyze length" pada kolom "comment".

Kemampuan program untuk melakukan proses perancangan pada bagian-bagian sentral tersebut akan membuat para pembuat shoe last dapat merekontruksi anatomi baru (Gambar 10). Hal ini akan efektif untuk digunakan pada perancangan shoe last dengan kebutuhan khusus, yaitu untuk mereplikasi kaki pengguna sepatu yang memiliki anatomi kaki dengan bentuk dan dimensi khusus atau spesial. 


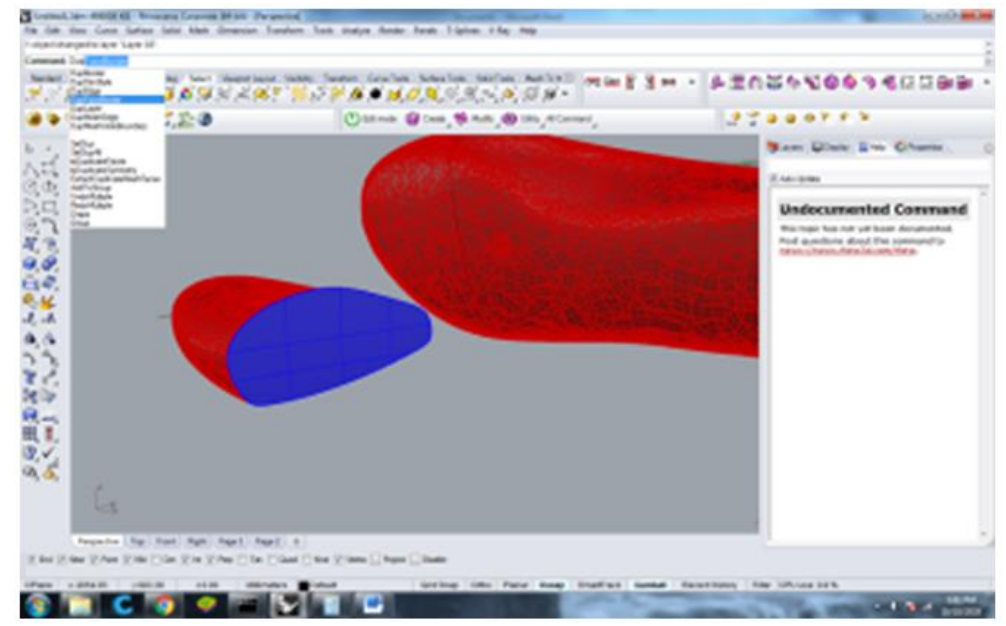

Gambar 10. Penggunaan program Rhinoceros pada rekonstruksi dan modifikasi bagian-bagian penting shoe last melalui pemodelan 3D

\section{KESIMPULAN}

Penelitian ini telah menunjukkan karakteristik dimensional anatomi kaki komunitas masyarakat lokal yang hasilnya dapat digunakan sebagai dimensi acuan pada proses pembuatan shoe last oleh industri-industri alas kaki yang ada disekitar kota Bandung. Hal ini akan sangat bermanfaat bagi para pelaku usaha alas kaki tersebut karena dengan menggunakan data riil anatomi kaki para calon konsumen sebagai dasar pembentukan shoe last, maka mereka dapat menekan nilai investasi untuk pengadaan alat bantu produksi sepatu tersebut. Disamping itu dengan penggunaan ukuran antropometri yang dijadikan standar tersebut, maka akan memudahkan kesamaan persepsi antara produsen dan konsumen terhadap ukuran/penomoran produk sepatunya. Hal ini akan menjadi sangat krusial ketika kegiatan perdagangan mulai bergeser pada bentuk perdagangan digital yang membuat konsumen tidak mungkin lagi mencoba sepatu yang pas dengan kaki sebelum memutuskan untuk membelinya.

Pembuatan produk shoe last yang dibantu dengan teknologi digital dalam proses perancangan dan produksinya sudah menjadi kebutuhan yang faktual dalam masyarakat modern seperti saat ini. Tidak hanya dibutuhkan oleh industri-industri alaskaki dalam skala manufaktur, tapi industri kecil/IKM sebaiknya juga dapat menggunakan teknologi tersebut dalam kegiatan usahanya. Pembuatan shoe last acuan yang biasanya harus dibuat dalam waktu dan proses yang lama, akan dapat direduksi menjadi lebih cepat dengan keakuratan bentuk dan ukuran yang dapat dijaga kualitasnya. Melalui teknologi digital modeling tersebut, model-model sepatu atau produk alas kaki lainnya akan dapat dikembangkan dengan cepat dan dalam kreasi yang tak terhingga. Keunggulan teknologi digital tersebut tentunya diharapkan akan dapat meningkatkan kemampuan kreasi para pelaku usaha alas kaki sehingga dapat meningkatkan pula daya saing mereka dalam pasar global yang sekarang sedang mereka jalani. 


\section{UCAPAN TERIMA KASIH}

Terimakasih kepada KEMENRISTEK DIKTI Republik Indonesia yang telah memberikan dukungan anggaran untuk pelaksanaan kegiatan ini. Terima kasih kepada Institut Teknologi Nasional - Bandung yang telah memberikan kesempatan dan dukungan fasilitas sehingga penelitian ini dapat diselesaikan. Juga kepada setiap pihak yang telah memberikan kontribusi dalam bentuk kerja, fasilitas, akses sehingga proses penelaahan, pengkajian dan penetapan kesimpulan penelitian tentang bentuk anatomi kaki responden lokal dapat direkonstruksi menjadi shoe last standar dan menghasilkan rekomendasi untuk dapat digunakan oleh IKM alas kaki di sekitar kota Bandung.

\section{DAFTAR PUSTAKA}

[1] Y. Chi Lee, W. Yu Chao and M. Jiun Wang, "Developing a New Foot Shape and Size System for Taiwanese Females," in The 19th International Conference on Industrial Engineering and Engineering Management, Berlin, 2013.

[2] L.-Y. Lin and C.-H. Chen, "Innovation and ergonomics consideration for female footwear," in 6 th International Conference on Applied Human Factors and Ergonomics (AHFE 2015) and the Affiliated Conferences, 2015.

[3] H. Branthwaite, N. Chockalingam, A. Greenhalgh and P. Chatzistergos, "The impact of different footwear characteristics, of a ballet flat pump,on centre of pressure progression and perceived comfort," http://www.elsevier.com/, pp. 116-122, 2014.

[4] J. Akambase, T. Kokoreva and O. Gurova, "RACIAL AND GENDER COMPARISON OF ANTHROPOMETRIC PARAMETERS OF THE FO," E u r o m e d i c a, pp. 55-56, 2018.

[5] M. Kouchi, "Foot Dimensions and Foot Shape: Differences Due to Growth, Generation and Ethnic Origin," Anthropological Science, pp. 161-188, 1998.

[6] sioux-shop.co.uk, "FINDING THE RIGHT SHOE SIZE WITH SIOUX," 2110 2020. [Online]. Available: https://www.sioux-shop.co.uk/cms/shoe-know-how/shoe-size-and-fit/shoe-size-conversion/.

[7] R. S. Goonetilleke, A. Luximon and K. L. Tsui, "The Quality of Footwear Fit: What we know, don't know and should know," in The IEA 2000/HFES 2000 Congress, 2000.

[8] R. S. Goonetilleke and A. Luximon, "Designing for Comfort: A Footwear Application," in Computer-Aided Ergonomics and Safety, 2001.

[9] S. and H. W. Murti, "KAJIAN INDUSTRI 4.0 UNTUK PENERAPANNYA DI INDONESIA," Jurnal Manajemen Industri dan Logistik, vol. 03, no. 01, pp. 1 - 13, 2019.

[10] K. Baba, "FOOT MEASUREMENT FOR SHOE CONSTRUCTION WITH REFERENCE TO THE RELATIONSHIP BETWEEN FOOT LENGTH, FOOT BREADTH, AND BALL GIRTH," Human Ergol, vol. 3, pp. 149 - 156, 1975. 